\title{
PENGARUH JENIS INOKULAN DAN DOSIS KOMPOS DALAM FITOREMEDIASI MENGGUNAKAN TANAMAN RAMI
}

\section{(THE EFFECT OF INOCULANT TYPE AND COMPOST DOSAGE IN PHYTOREMEDIATION PROCESS USING RAMIE PLANT)}

\author{
Desvia Diyanti Nursyabani, Pudjawati Suryatmana, dan Rija Sudirja \\ Fakultas Pertanian Universitas Padjadjaran \\ J1. Raya Bandung-Sumedang KM. 21, Kabupaten Sumedang, Jawa Barat \\ email: desviadn@gmail.com
}

\begin{abstract}
Abstrak
Penelitian ini bertujuan untuk mengetahui interaksi antara pemberian jenis inokulan dan kompos rami terhadap laju degradasi hidrokarbon, total populasi Azospirillum sp., dan diameter batang rami. Penelitian ini dilaksanakan dari bulan November 2017 sampai dengan Februari 2018 di Laboratorium Biologi Tanah, Laboratorium Kimia Tanah dan Nutrisi Tanaman, Rumah Kaca dan Kebun Percobaan Fakultas Pertanian Universitas Padjadjaran. Penelitian ini menggunakan rancangan percobaan acak kelompok (RAK) faktorial yang terdiri dari dua faktor yaitu jenis inokulan dan dosis kompos. Perhitungan total populasi Azospirillum sp. dengan metode Total Plate Count (TPC) dan pengukuran kadar Total Petroleum Hidrokarbon (TPH) dengan metode gravimetri. Berdasarkan hasil penelitian dapat disimpulkan bahwa faktor perlakuan jenis inokulan dan dosis kompos pada fitoremediasi tanah tercemar hidrokarbon minyak bumi tidak menunjukkan adanya pengaruh interaksi terhadap laju degradasi hidrokarbon, total populasi Azospirillum sp., dan diameter batang tanaman rami. Terjadi pengaruh mandiri faktor perlakuan dosis kompos terhadap laju degradasi hidrokarbon dan diameter batang tanaman rami. Pengaruh mandiri dosis kompos rami memberikan hasil terbaik pada dosis $2,5 \%(\mathrm{w} / \mathrm{w})$ terhadap peningkatan diameter batang tanaman rami.
\end{abstract}

Kata kunci: inokulan, kompos, fitoremediasi, rami

\begin{abstract}
This study was aimed at determining the interaction between the administration of inoculant types and hemp compost to the rate of hydrocarbon degradation, the total population of Azospirillum sp., and the diameter of the hemp stem. This study was conducted from November 2017 to February 2018 in the Soil Biology Laboratory, Soil Chemistry, and Plant Nutrition Laboratory, Greenhouse and Experimental Gardens, Faculty of Agriculture, Padjadjaran University. This study used a Randomized Complete Block Design (RCBD) consisting of two factors: the type of inoculant and compost dose. Calculation of the total population of Azospirillum sp. by the Total Plate Count (TPC) method and measurement of Total Petroleum Hydrocarbon (TPH) levels by the gravimetric method. Based on the results, it can be concluded that the factor of inoculant treatment and compost dosage in phytoremediation of petroleum hydrocarbon polluted soils does not show any interaction effect on the rate of hydrocarbon degradation, total population of Azospirillum sp., and stem diameter of hemp plants. There is an independent effect of compost dose treatment factor on the rate of hydrocarbon degradation and stem diameter of the hemp plant. The independent effect of hemp compost dose gives the best results at a dose of $2.5 \%$ $(\mathrm{w} / \mathrm{w})$ to increase the diameter of the hemp plant stems.
\end{abstract}

Keywords: inoculant, compost, phytoremediation, ramie 


\section{PENDAHULUAN}

Salah satu sumber daya alam yang penting di Indonesia adalah minyak bumi. Minyak bumi mempunyai manfaat sebagai penghasil bahan bakar untuk transportasi dan mesin-mesin industri. Minyak bumi terbentuk dari dekomposisi fosil-fosil tumbuhan dan hewan selama berjuta-juta tahun yang mengandung berbagai senyawa kimia seperti vanadium, nikel, natrium, besi, aluminium, kalsium, magnesium, dan hidrokarbon (Brown, Chaney, Angle, \& Baker, 1995).

Produksi minyak bumi di Indonesia diperkirakan akan terus menurun. Hal ini berbanding terbalik dengan jumlah konsumsinya. Produksi minyak bumi di Indonesia tahun 2014 hanya sebesar 852 ribu barel per hari dengan laju penurunan produksi mencapai 3,07\%. Konsumsi minyak bumi di Indonesia diperkirakan sudah mencapai 1,6 juta barel per hari (BPstats, 2015). Hal ini menunjukkan tingginya jumlah konsumsi minyak bumi di Indonesia yang berdampak pada berbagai masalah misalnya pencemaran lingkungan.

Nuryatini dan Wiloso (2010) menjelaskan bahwa sumber pencemaran minyak bumi dapat berasal dari kecelakaan transportasi, kebocoran pipa, dan kegiatan eksplorasi minyak bumi yang menghasilkan tumpahan minyak (oilspill). Tumpahan minyak tersebut dapat menguap, tersapu air hujan, atau masuk ke dalam tanah. Hal ini berhubungan langsung dengan kehidupan manusia ketika bersentuhan karena mencemari air dan tanah akibat terendap sebagai zat kimia beracun. Efek lain dari pencemaran oleh minyak bumi adalah terdegradasinya fungsi tanah dan menurunnya kestabilan tanah yang berujung pada lahan kritis (Sulistyono, Suntoro, \& Masykuri, 2012).

Salah satu contoh kasus tumpahan minyak (crude oil) adalah pada Kilang Minyak Pusdiklat Migas (Cepu) yang terjadi pada saat loading dan unloading di tangki timbun (storage tank), pembersihan tangki timbun (tank cleaning), pada proses di separator dan pompa feed maupun pompa produk. Menurut Pusdiklat Minyak pada tahun 2011 minyak yang hilang (losses) karena menguap, tumpah maupun tercecer selama proses produksi rata-rata $0,4 \%$ atau 108,38 barrel per bulan atau 17.232,42 liter per bulan. Diasumsikan dari jumlah tersebut jumlah minyak yang menguap sebanyak $70 \%$, maka jumlah minyak yang tumpah dan tercecer di sekitar kilang sebanyak 5.169,73 liter per bulan atau rata-rata sebanyak 62.036 liter per tahun.

Salah satu kontaminan toksik yang paling sukar diurai dari tumpahan minyak bumi adalah hidrokarbon. Senyawa ini berdampak buruk bagi manusia dan lingkungan. Hidrokarbon terdiri dari karbon dan hidrogen dan terdapat pada minyak 
bumi dan turunannya. Senyawa ini sering dimanfaatkan manusia dan berpotensi mencemari lingkungan (Notodarmojo, 2005). Pertumbuhan tanaman dan organisme lain yang hidup di dalam tanah akan terganggu karena keberadaan kontaminan tersebut. Hal ini menyebabkan perlunya penanganan khusus untuk menjaga kualitas dan daya dukung lingkungan (Alexander, 1999).

Upaya pemulihan lahan tercemar minyak bumi perlu dilakukan untuk mencegah penyebaran pada penyerapan minyak ke dalam tanah. Metode alternatif yang dapat digunakan secara efektif dan efisien adalah fitoremediasi. Fitoremediasi adalah teknologi pemanfaatan tanaman sebagai penghilang polutan berbahaya, seperti logam berat, pestisida, dan senyawa organik (Priyanto \& Prayitno, 2007). Metode ini mempunyai keunggulan yaitu sederhana, efisien, hemat biaya, murah, dan ramah lingkungan sehingga sangat berkembang pesat (Schnoor \& McCutcheon, 2003).

Tanaman yang dapat bertahan pada konsentrasi pencemaran yang tinggi dan tidak untuk dikonsumsi adalah salah satu karakteristik tanaman fitoremedian yang baik (Chaudhry, Hayes, Khan, \& Khoo 1998). Beberapa tahun terakhir para peneliti merekomendasikan tanaman Rami (Boehmeria nivea (L.) Gaud) sebagai tanaman fitoremedian (Hindersah, Nurbaity, \& Nursyamsi, 2015). Rami termasuk jenis tanaman tahunan berumpun yang menghasilkan serat dari kulit kayunya serta relatif mudah dibudidayakan. Batang tanaman rami tinggi ramping hingga mencapai ketinggian antara 200-250 cm (Defirman, 2016). Selain itu, tanaman rami memiliki biomassa yang tinggi dan beradaptasi dengan baik pada kondisi pertumbuhan yang tidak menguntungkan seperti kekeringan, tanah yang tidak subur, penyakit, dan hama serangga (Wei et al., 2011). Tanaman rami secara dominan ditemukan dan telah banyak didokumentasikan pada berbagai tempat penambangan logam, serta dapat mengakumulasi logam $\mathrm{Sb}, \mathrm{Cd}$, dan $\mathrm{Hg}$ dengan tinggi.

Kadar Total Petroleum Hydrocarbon (TPH) yang terkandung pada minyak bumi dapat menurunkan jumlah populasi sebagian mikroba pada tanah yang tercemar (Saadoun, Mohammad, Hameed, \& Shawaqfah, 2008). TPH mempunyai karakteristik yang sukar larut antara air dan minyak sehingga diperlukan senyawa yang dapat meningkatkan efisiensi degradasi hidrokarbon yaitu biosurfaktan. Senyawa ini dapat mengemulsi kelarutan minyak dalam air sehingga luas permukaan antara minyak dengan air semakin besar. Jumlah persentase TPH dapat menurun karena terjadi metabolisme mikroorganisme untuk mendegradasi hidrokarbon (Abouseoud, Maachi, Amrane, Boudergua, \& Nabi, 2008). 
Pengaruh Jenis Inokulan (Nursyabani, D. D., Suryatmana, P., \& Sudirja, R.

Pada penelitian ini dilakukan pengaplikasian inokulan Azotobacter vinelandii dan Azospirillum sp. sebagai penghasil biosurfaktan dan biofertilizer yang dapat menyediakan unsur hara dan fitohormon bagi tanaman rami dan merangsang pertumbuhan populasi bakteri petrofilik indigenous.

Penambahan kompos rami dilakukan sebagai bulking agent. Bulking agent tersebut berfungsi sebagai pengatur porositas, kelembaban, dan sumber nutrisi (Larasati \& Mulyana, 2013). Berdasarkan latar belakang di atas, pemanfaatan inokulan Azotobacter vinelandii, Azospirillum sp., dan kompos rami dalam fitoremediasi tanah tercemar minyak bumi perlu dikaji lebih lanjut untuk mengetahui pengaruh antar perlakuan terhadap efisiensi degradasi hidrokarbon, populasi Azospirillum sp. serta diameter batang tanaman rami.

\section{METODE PENELITIAN}

Penelitian dilaksanakan di Laboratorium Biologi Tanah dan Laboratorium Kesuburan Tanah dan Nutrisi Tanaman Departemen Ilmu Tanah dan Sumber Daya Lahan, serta Rumah Kaca Kebun Percobaan Fakultas Pertanian Universitas Padjadjaran, Kecamatan Jatinangor Kabupaten Sumedang Jawa Barat dengan ketinggian 822 mdpl. Penelitian dilakukan mulai bulan November 2017 sampai dengan Februari 2018.
Alat yang digunakan pada penelitian ini antara lain: peralatan untuk analisis kimia, peralatan untuk analisis TPC (petridish, pipet ukur, dan tabung reaksi), peralatan untuk analisis TPH (botol kocok, botol vial, alumunium foil, kertas filter, dan rotary shaker), jangka sorong untuk mengukur diameter batang rami, peralatan untuk analisis parameter penunjang $(\mathrm{pH}$ meter, thermometer, soil moisture tester, dan fluks meter), laminar air flow, autoclave, incubator, ose, spatula, kertas label, gelas ukur, cangkul, timbangan, selang, sprayer, pisau, penggaris, emrat, sekop, sendok tembok, dan polybag kapasitas $5 \mathrm{~kg}$.

Bahan-bahan yang digunakan dalam penelitian ini antara lain: tanah Inceptisol Jatinangor; minyak bumi yang berasal dari Pertamina Balongan-Indramayu; tanaman rami klon Lembang yang berasal dari Wonosobo Jawa Tengah yang diperbanyak menggunakan rimpang tanaman rami; inokulan mikroba Azotobacter vinelandii, Azospirillum sp., bakteri petrofilik Pseudomonas cepacea, fungi petrofilik Aspergillus niger yang merupakan koleksi Laboratorium Biologi Tanah Fakultas Pertanian Universitas Padjadjaran; media biakan isolasi mikroba indigenus yaitu Ashby, PDA, TSA, Okon, dan NA; kompos dari tanaman rami; pupuk dasar N, P, K; bahan kimia untuk penghitungan TPH yaitu n-heksan. 
Penelitian ini menggunakan metode Rancangan Acak Kelompok (RAK) faktorial dengan menggunakan dua faktor untuk mengetahui interaksi antara dua faktor. Faktor pertama pada penelitian ini adalah pemberian inokulan (Azotobacter vinelandii., Azospirillum sp., bakteri petrofilik Pseudomonas cepacea, fungi petrofilik Aspergillus niger) sebagai inokulan yang terdiri dari 6 taraf. Faktor kedua adalah pemberian kompos tanaman rami sebagai bulking agent yang terdiri dari 4 taraf. Jumlah kombinasi perlakuan pada penelitian ini sebanyak $6 \times 4=24$ dengan kombinasi ulangan perlakuan sebanyak 3 ulangan sehingga didapat seluruh total satuan percobaan sebanyak 72 satuan percobaan. Perhitungan total populasi Azospirillum sp. dengan metode total plate count (TPC), dan pengukuran kadar TPH dengan metode gravimetri.

\section{HASIL DAN PEMBAHASAN}

Faktor jenis inokulan dan dosis kompos tidak menunjukkan adanya pengaruh interaksi, tetapi salah satu faktor yaitu dosis kompos rami menunjukkan adanya pengaruh mandiri terhadap laju degradasi hidrokarbon. Faktor jenis inokulan sendiri, tidak menunjukkan pengaruh nyata terhadap laju degradasi hidrokarbon. Nilai rata-rata laju degradasi hidrokarbon pada setiap taraf faktor perlakuan disajikan pada Tabel 1 .
Faktor jenis inokulan tidak berpengaruh nyata terhadap nilai laju degradasi hidrokarbon minyak bumi disebabkan oleh faktor lingkungan yaitu kelembaban udara di dalam rumah kaca yang terlalu rendah dan $\mathrm{pH}$ tanah yang cenderung masam. Kelembaban rumah kaca dari awal penelitian hingga akhir cenderung mengalami naik dan turun pada kisaran 76,86\% hingga 84,14\% dengan ratarata kelembaban $80,26 \%$. Kelembaban udara optimal bagi tanaman rami berkisar $83-89 \%$ (Wulandari, 2015) sehingga kelembaban udara rumah kaca tersebut tidak sesuai untuk pertumbuhan tanaman rami.

Selama proses fitoremediasi, $\mathrm{pH}$ tanah menunjukkan tren penurunan sehingga $\mathrm{pH}$ pada T13 adalah kisaran 5,7-6,7. Umumnya kisaran $\mathrm{pH}$ optimum bagi pertumbuhan bakteri adalah 6,5-7,5 dan proses biodegradasi hidrokarbon berlangsung optimal pada pH 6,5-8 (Chair, Goldsmith, \& Evanylo, 2001). Kondisi lingkungan berupa pH dan kelembapan udara rumah kaca yang tidak optimal bagi pertumbuhan tanaman rami, mikroba, dan proses degradasi ini menyebabkan laju degradasi hidrokarbon yang tidak maksimal dan tidak berpengaruh nyata.

Pemberian kompos rami sebagai faktor perlakuan dalam penelitian ini memberi pengaruh mandiri terhadap nilai laju degradasi hidrokarbon. Taraf perlakuan kompos rami 7,5\% (w/w) $\left(b_{3}\right)$ 
Pengaruh Jenis Inokulan (Nursyabani, D. D., Suryatmana, P., \& Sudirja, R.

Tabel 1

Pengaruh Jenis Inokulan dan Dosis Kompos terhadap Laju Degradasi Hidrokarbon Minyak Bumi pada $T_{13}\left(H_{92}\right)$

\begin{tabular}{lc}
\hline \multicolumn{1}{c}{ Perlakuan } & $\begin{array}{c}\text { Laju Degradasi Hidrokarbon } \\
(\% / \text { minggu })\end{array}$ \\
\hline Jenis Inokulan $(\mathrm{A})$ & 0,16 \\
$\mathrm{a}_{0}=$ Kontrol & 0,16 \\
$\mathrm{a}_{1}=$ Azotobacter vinelandii & 0,17 \\
$\mathrm{a}_{2}=$ Azospirillum $\mathrm{sp}$. & 0,17 \\
$\mathrm{a}_{3}=$ Pseudomonas cepaceae & 0,17 \\
$\mathrm{a}_{4}=$ Aspergillus niger & 0,14 \\
$\mathrm{a}_{5}=$ Konsorsium & \\
Kompos Rami (B) & $0,16 \mathrm{ab}$ \\
$\mathrm{b}_{0}=$ Kontrol) & $0,16 \mathrm{ab}$ \\
$\mathrm{b}_{1}=2,5 \%$ (w/w) & $0,15 \mathrm{a}$ \\
$\mathrm{b}_{2}=5 \%$ (w/w) & $0,18 \mathrm{~b}$ \\
$\mathrm{~b}_{3}=7,5 \%$ (w/w) & \\
Keterangan: Angka yang tidak diikuti notasi huruf menandakan faktor \\
perlakuan tidak berpengaruh nyata terhadap respons berdasarkan \\
analisis ragam pada taraf nyata 5\%. Angka yang diikuti oleh notasi \\
huruf yang sama menandakan taraf-taraf faktor perlakuan tidak berbeda \\
nyata berdasarkan uji lanjut Duncan pada taraf nyata $5 \%$.
\end{tabular}

berpengaruh paling tinggi dibanding taraf perlakuan lainnya yaitu $5 \%(\mathrm{w} / \mathrm{w})\left(\mathrm{b}_{2}\right)$. Hal ini disebabkan oleh fungsi kompos rami yang berperan baik sebagai bulking agent. Bulking agent meningkatkan degradability tanah karena bahan organik yang terkandung di dalamnya, selain itu juga berfungsi untuk mengatur porositas, kelembapan dan sumber nutrisi (Anderson, 1995). Porositas tanah sangat berpengaruh terhadap laju degradasi hidrokarbon karena air akan lebih mudah diserap oleh tanah sehingga kontaminan hidrokarbon lebih mudah terurai.

Kadar N-total pada kompos rami yang tinggi yaitu 1,06\% juga berpengaruh pada proses biodegradasi. Nutrisi adalah salah satu komponen yang berpengaruh pada pertumbuhan sel dan aktivitas enzim mikroba dalam proses biodegradasi. Nitrogen dibutuhkan oleh mikroba sebagai penyusun senyawa-senyawa penting dalam selnya (Shewfelt, Lee, \& Zytner, 2005). Kadar nitrogen yang melimpah pada kompos rami memungkinkan mikroba bekerja lebih baik dalam mendegradasi hidrokarbon dan meningkatkan laju degradasi.

Faktor jenis inokulan dan dosis kompos tidak menunjukkan adanya pengaruh interaksi, tetapi salah satu faktor yaitu dosis kompos rami menunjukkan adanya 
pengaruh mandiri terhadap diameter batang tanaman rami. Faktor jenis inokulan sendiri, tidak menunjukkan pengaruh nyata terhadap diameter batang tanaman rami. Nilai ratarata diameter batang tanaman rami pada setiap taraf faktor perlakuan disajikan pada Tabel 2.

Pupuk anorganik tunggal N, P, dan K yang digunakan pada penelitian ini adalah $1 / 2$ dosis anjuran yang berfungsi untuk mendukung pertumbuhan tanaman. Penggunaan inokulan selain dapat mendegradasi hidrokarbon, diharapkan juga dapat menyubtitusi kebutuhan nutrisi untuk pertumbuhan tanaman salah satunya pertumbuhan batang rami. Ternyata faktor jenis inokulan tidak menunjukkan pengaruh nyata terhadap pertumbuhan diameter batang rami. Hal ini disebabkan oleh mekanisme kompetisi antarmikroba yang diintroduksikan dan mikroba indigenus sehingga tidak dapat menghasilkan nutrisi yang optimal bagi pertumbuhan tanaman (Mohapatra, 2008). Dalam penelitian ini mikroba-mikroba di dalam tanah berkompetisi menggunakan karbon sebagai sumber nutrisi dan energinya. Bakteri penambat nitrogen seperti Azotobacter sp. dan Azospirillum sp. harus

Tabel 2

Pengaruh Jenis Inokulan dan Dosis Kompos terhadap Diameter Batang Tanaman Rami pada $T_{13}\left(H_{9}\right)$

\begin{tabular}{lc}
\hline \multicolumn{1}{c}{ Perlakuan } & $\begin{array}{c}\text { Diameter Batang } \\
(\mathrm{mm})\end{array}$ \\
\hline Jenis Inokulan (A) & \\
$\mathrm{a}_{0}=$ Kontrol & 4,38 \\
$\mathrm{a}_{1}=$ Azotobacter vinelandii & 4,41 \\
$\mathrm{a}_{2}=$ Azospirillum sp. & 4,55 \\
$\mathrm{a}_{3}=$ Pseudomonas cepaceae & 4,36 \\
$\mathrm{a}_{4}=$ Aspergillus niger & 4,51 \\
$\mathrm{a}_{5}=$ Konsorsium & 4,83 \\
Kompos Rami (B) & \\
$\mathrm{b}_{0}=$ Kontrol) & $4,37 \mathrm{a}$ \\
$\mathrm{b}_{1}=2,5 \%(\mathrm{w} / \mathrm{w})$ & $4,82 \mathrm{~b}$ \\
$\mathrm{~b}_{2}=5 \%(\mathrm{w} / \mathrm{w})$ & $4,27 \mathrm{a}$ \\
$\mathrm{b}_{3}=7,5 \%(\mathrm{w} / \mathrm{w})$ & $4,57 \mathrm{ab}$ \\
\hline $\mathrm{K}$
\end{tabular}

Keterangan: Angka yang tidak diikuti notasi huruf menandakan faktor perlakuan tidak berpengaruh nyata terhadap respons berdasarkan analisis ragam pada taraf nyata 5\%. Angka yang diikuti oleh notasi huruf yang sama menandakan taraf-taraf faktor perlakuan tidak berbeda nyata berdasarkan uji lanjut Duncan pada taraf nyata 5\%. 


\section{Pengaruh Jenis Inokulan (Nursyabani, D. D., Suryatmana, P., \& Sudirja, R.}

bersaing dengan mikroba lain seperti mikroba petrofilik indigenus untuk memperoleh karbon yang jumlahnya terbatas yaitu $<1 \%$ pada $\mathrm{T}_{13}\left(\mathrm{H}_{91}\right)$. Padahal mikroba memerlukan $50 \%$ unsur karbon untuk pembentukan biomassa selnya sehingga kerja mikroba untuk menyediakan unsur hara untuk tanaman terhambat dan lebih fokus untuk mendegradasi hidrokarbon di dalam tanah.

Pengaruh mandiri kompos rami terhadap diameter batang menunjukkan bahwa taraf faktor perlakuan $b_{1}$ yaitu kompos 2,5\% (w/w) menghasilkan nilai yang lebih tinggi dan berbeda nyata dibandingkan taraf faktor perlakuan $b_{0}$ (tanpa kompos rami) dan $\mathrm{b}_{2}$ (kompos 5\% w/w). Rami adalah salah satu tanaman yang mempunyai sifat rakus akan hara karena mempunyai pertumbuhan vegetatif yang cepat. Tanaman ini tumbuh optimal pada tanah yang memiliki bahan organik tinggi (Mayerni, 2006).

Pada penelitian ini tanah yang tercemar oleh minyak bumi mengalami penambahan bahan organik yaitu bulking agent berupa kompos rami sehingga berpengaruh pada pertumbuhan tanaman rami. Namun, nilai rasio $\mathrm{C} / \mathrm{N}$ pada kompos akan mempengaruhi ketersediaan unsur hara dalam tanah. Novizan (2005) menyatakan bahwa kompos yang baik adalah yang mengandung $\mathrm{C} / \mathrm{N}$ rasio $12-15$, sedangkan rasio $\mathrm{C} / \mathrm{N}$ yang terkandung pada kompos rami tergolong rendah yaitu 8,17. Mikroorganisme membutuhkan unsur karbon (C) dan nitrogen (N) untuk pertumbuhan dan penyusun struktur sel. Apabila rasio $\mathrm{C} / \mathrm{N}$ terlalu rendah, hal ini akan meningkatkan emisi dari nitrogen. Kelebihan nitrogen yang tidak dipakai oleh mikroorganisme tidak dapat diasimilasi dan akan hilang melalui volatisasi sebagai amoniak ke atmosfer atau terdenitrifikasi (Djuarnani, 2005; Shewfelt et al., 2005). Hal ini dapat menekan perkembangbiakan mikroba dan kurangnya unsur hara nitrogen dalam tanah. Oleh karena itu, faktor perlakuan $b_{1}$ yaitu kompos 2,5\% (w/w) lebih berpengaruh nyata dan optimal bagi pertumbuhan diameter batang rami dibanding perlakuan dosis kompos lain.

Faktor jenis inokulan dan dosis kompos tidak menunjukkan adanya pengaruh interaksi maupun pengaruh mandiri terhadap total populasi Azospirillum sp. Hal ini dapat dipengaruhi beberapa faktor antara lain mekanisme antagonisme antarmikroba dan keadaan $\mathrm{pH}$ tanah yang tidak mendukung bagi pertumbuhan mikroba (Tabel 3).

Mekanisme antagonisme terjadi pada perlakuan konsorsium $\left(\mathrm{A}_{5}\right)$. Hal ini disebabkan kompetisi mikroba untuk memperoleh nutrisi seperti $\mathrm{C}, \mathrm{N}$, dan $\mathrm{P}$ yang jumlahnya terbatas (Singh \& Dwivedi, 2004). Pada perlakuan penambahan inokulan bakteri dan jamur petrofilik berupa Pseudomonas 
Tabel 3

Pengaruh Jenis Inokulan dan Dosis Kompos terhadap Total Populasi Azospirillum sp. pada $T_{13}\left(H_{92}\right)$

\begin{tabular}{lc}
\hline \multicolumn{1}{c}{ Perlakuan } & $\begin{array}{c}\text { Populasi Azospirillum sp. } \\
\left(\text { cfu g }^{-1}\right)\end{array}$ \\
\hline Jenis Inokulan (A) & \\
$\mathrm{a}_{0}=$ Kontrol & 165000 \\
$\mathrm{a}_{1}=$ Azotobacter vinelandii & 216670 \\
$\mathrm{a}_{2}=$ Azospirillum sp. & 185000 \\
$\mathrm{a}_{3}=$ Pseudomonas cepaceae & 180000 \\
$\mathrm{a}_{4}=$ Aspergillus niger & 171670 \\
$\mathrm{a}_{5}=$ Konsorsium & 206670 \\
Kompos Rami (B) & \\
$\mathrm{b}_{0}=$ Kontrol) & 167780 \\
$\mathrm{~b}_{1}=2,5 \%(\mathrm{w} / \mathrm{w})$ & 182220 \\
$\mathrm{~b}_{2}=5 \%$ (w/w) & 188890 \\
$\mathrm{~b}_{3}=7,5 \%$ (w/w) & 211110 \\
\hline Keterangan: Angka yang tidak diikuti notasi huruf menandakan \\
faktor perlakuan tidak berpengaruh nyata terhadap respons \\
berdasarkan analisis ragam pada taraf nyata $5 \%$.
\end{tabular}

cepaceae $\left(\mathrm{A}_{3}\right)$ dan Aspergilus niger $\left(\mathrm{A}_{4}\right)$ terdapat kompetisi dalam memperoleh substrat karbon. Terutama pada akhir penelitian ini $\left(\mathrm{T}_{13}\right)$ kadar total petroleum hidrokarbon (TPH) sudah sangat sedikit $<1 \%$. Kemungkinan lain yang terjadi adalah, terdapat senyawa toksik yang resisten dari hidrokarbon salah satunya adalah Dibenzotiofen. Dibenzotiofen termasuk salah satu senyawa PAH yang memiliki 3 cincin benzena yang sangat hidrofobik sehingga sangat sulit diurai oleh mikroba (Cerniglia, 1992). Hal ini menyebabkan perlakuan tersebut tidak menunjukkan pengaruh nyata terhadap total populasi Azospirillum sp.
Hal lain yang berpengaruh adalah kondisi tanah pada penelitian ini. Pada $\mathrm{T}_{0}(0-$ 14 HSP) seiring dengan penambahan crude oil, bulking agent, dan inokulan $\mathrm{pH}$ tanah berkisar 7-7,5. Sebaliknya pada $\mathrm{T}_{13}$ nilai $\mathrm{pH}$ tanah mengalami penurunan dari nilai $\mathrm{pH}$ pada $T_{0}$ yaitu kisaran 5,7-6,7 dengan ratarata $\mathrm{pH}$ tanah adalah 6,19 . Kisaran $\mathrm{pH}$ yang optimal untuk pertumbuhan bakteri yaitu 6,57,5 (Pelczar \& Chan, 2005). Hal ini dapat dijadikan faktor lain jenis inokulan tidak berpengaruh nyata terhadap total populasi Azospirillum sp. karena lingkungan yang tidak optimal bagi pertumbuhan bakteri.

Faktor dosis kompos rami juga tidak berpengaruh nyata terhadap total populasi 
Azospirillum sp. Hal ini disebabkan oleh bahan baku kompos yaitu tanaman rami. Ekstrak air yang dihasilkan oleh daun rami terbukti berfungsi sebagai antimikroba (Chang, Huang, Yuan, Lai, \& Hung, 2010). Selain itu, batang tanaman rami memiliki ketahanan yang baik terhadap mikroba dan jamur (Novarini \& Sukarda, 2015). Hal ini menyebabkan kompos yang terbuat dari tanaman rami menekan pertumbuhan mikroba, salah satunya Azospirillum sp.

\section{SIMPULAN}

Berdasarkan hasil penelitian dapat disimpulkan bahwa faktor perlakuan jenis inokulan dan dosis kompos pada fitoremediasi tanah tercemar hidrokarbon minyak bumi tidak menunjukkan adanya pengaruh interaksi terhadap laju degradasi hidrokarbon, total populasi Azospirillum sp., dan diameter batang tanaman rami. Terjadi pengaruh mandiri faktor perlakuan dosis kompos terhadap laju degradasi hidrokarbon dan diameter batang tanaman rami. Pengaruh mandiri dosis kompos rami memberikan hasil terbaik pada dosis $2,5 \%(\mathrm{w} / \mathrm{w})$ terhadap peningkatan diameter batang tanaman rami.

\section{DAFTAR PUSTAKA}

Abouseoud, M., Maachi, R., Amrane, A., Boudergua, S., \& Nabi, A. (2008). Evaluation of different carbon and nitrogen sources in production of biosurfactant by Pseudomonas fluorescens. Desalination, 223(1-3), 143-151.
Alexander, M. (1999). Biodegradation and bioremediation ( $2^{\text {nd }}$ ed.). Oxford: Gulf Professional Publishing.

Anderson, W. C. (1995). Innovative remediation technology (Bioremediation). USA: Water Environment Federation.

BPstats. (2015). BP statistical review of world energy $\left(64^{\text {th }}\right.$ ed.). Diunduh dari https://biomasspower.gov.in/document/ Reports/B P\%20statistica 1\%20 review-2015.pdf.

Brown, S. L., Chaney, R. L., Angle, J. S., \& Baker, A. J. M. (1995). Zinc and cadmium uptake by hyperaccumulator Thlaspi caerulescens grown in nutrient solution. Soil Science Society of America Journal, 59(1), 125-133.

Cerniglia, C. (1992). Biodegradation of polycyclic aromatic hydrocarbons. Biodegradation 3(2-3), 351-368.

Chair, J. T. N., Goldsmith, C. D., \& Evanylo, G. (2001). Enhanced biodegradation in landfills (Thesis). Master of Science Virginia Polytechnic and State University, Virginia.

Chang, J. M., Huang, K. L., Yuan T. T. T., Lai, Y. K., \& Hung, L. M. (2010). The antihepatitis B virus activity of boehmeria nivea extract in HBV-viremia SCID mice. eCAM, 7(2), 189-195.

Chaudhry, T. M., Hayes, W. J., Khan, A. G., \& Khoo, C. S. (1998). PhytoremediationFocusing on accumulator plants that remediate metal contaiminated soils. Australasian J. of Ecotoxicology, 4, 37 51.

Defirman. (2016). Respon tanaman rami (Boehmeria nivea L.Gaud) terhadap pemberian beberapa dosis fungi mikoriza arbuskula (FMA) pada ultisol (Skripsi tidak diterbitkan). Universitas Andalas, Padang.

Djuarnani, N. (2005). Cara cepat membuat kompos. Jakarta: Agromedia Pustaka. 
Hindersah, R., Nurbaity, A., \& Nursyamsi, D. (2015). Role of Nitrogen Fertilizer on Cadmium Uptake by Ramie (Boehmeria nivea (L.) Gaudich) Grown on Cadmium Contaminated Soil. Agrikultura, 26(1), 49-54.

Larasati, T. R. D., \& Mulyana, N. (2013). Bioremediasi lahan tercemar limbah lumpur minyak menggunakan campuran bulking agents yang diperkaya konsorsia mikroba berbasis kompos iradiasi. Jurnal Ilmiah Aplikasi Isotop dan Radiasi, 9(2), 139-150.

Mayerni, R. (2006). Prospek dan peluang tanaman rami di Indonesia. Padang: Universitas Andalas Press.

Mohapatra, P, K. (2008). Textbook of environmental microbiology. New Delhi: I. K. International Publishing House Pvt. Ltd.

Notodarmojo, S. (2005). Pencemaran tanah dan air tanah. Bandung: Penerbit ITB.

Novarini, E., \& Sukardan, M. D. (2015). Potensi serat rami (boehmeria nivea s. gaud) sebagai bahan baku industri tekstil dan produk tekstil dan tekstil teknik. Arena Tekstil, 30(2).

Nuryatini, \& Wiloso, E. I. (2012). Uji metode analisis minyak terdispersi dalam air. Teknologi Indonesia, 33(1).

Pelczar, M. J., \& Chan, E. C. S. (2005). Dasar-dasar mikrobiologi (Jilid 2). Jakarta: UI Press.

Priyanto, B., \& Prayitno, J. (2007). Fitoremediasi sebagai sebuah teknologi pemulihan pencemaran, khususnya logam berat. Diunduh dari http://ltl. bppt.tripod.com/sublab/lflora1.htm.

Saadoun, I., Mohammad, M. J., Hameed, K. M., \& Shawaqfah, M. (2008). Microbial populations of crude oil spill polluted soils at the Jordan-Iraq desert (The Badia region). Brazilian Journal of Microbiology, 39(3), 453-456.

Schnoor, J. L., \& McCutcheon, S. (2003). Phytoremediation transformation and control of contaminants. USA: WileyInterscience Inc.

Shewfelt, K., Lee, H., \& Zytner, R. G. (2005). Optimization of nitrogen for bioventing of gasoline contaminated soil. Journal of Environmental Engineering and Science, 4(1), 29-42.

Singh, D. P., \& Dwivedi, S. K. (2004). Environmental microbiology and biotechnology. New Delhi: New Age International Ltd., Publishers.

Sulistyono, Suntoro, \& Masykuri, M. (2012). Kajian dampak tumpahan minyak dari kegiatan operasi kilang minyak terhadap kualitas air dan tanah (Studi Kasus Kilang Minyak Pusdiklat Migas Cepu). Ekosains, 4(2), 23-34.

Wei, S., Yu-Cheng, J., Hu-Cheng, X., YanWei, L., Huang, M., Wan-Li, K, \& Dong, W. (2011). Tolerance to cadmium in ramie (Boehmeria nivea) genotypes and its evaluation indicators. Acta Agronomica Sinica, 37(2), 348-353.

Wulandari, A. P. (2015). Rami: Prospeksi serat dan limbah. Bandung: Unpad Press. 